\title{
Desiring the Secular: Capital, Cohesion, and the Fantasy of Secularization
}

\author{
Ian A. Morrison (D)
}

check for updates

Citation: Morrison, Ian A. 2021.

Desiring the Secular: Capital,

Cohesion, and the Fantasy of Secularization. Religions 12: 410. https://doi.org/10.3390/rel12060410

Academic Editors:

Svetlana Sharonova, Marta Soler and Daniel H. Levine

Received: 15 May 2021

Accepted: 2 June 2021

Published: 3 June 2021

Publisher's Note: MDPI stays neutral with regard to jurisdictional claims in published maps and institutional affiliations.

Copyright: (C) 2021 by the author. Licensee MDPI, Basel, Switzerland. This article is an open access article distributed under the terms and conditions of the Creative Commons Attribution (CC BY) license (https:/ / creativecommons.org/licenses/by/ $4.0 /)$.
Department of Sociology, Egyptology and Anthropology, The American University in Cairo, P.O. Box 74 AUC Avenue, New Cairo 11835, Egypt; imorrison@aucegypt.edu

\begin{abstract}
Towards the end of the twentieth century, religion re-emerged as a topic of pressing concern in a number of the most self-consciously secularized states of the global north. From disputes over the wearing of headscarves in schools to debates over accommodations for religious practices in the public sphere, religion, particularly the 'foreign' religiosity of migrants and other minority religious subjects, appeared on the scene as a phenomenon whose proper place and role in society required both urgent and careful deliberation. This article argues that in order to account for the affective potency produced by the immanence of the figure of the 'foreign' religious subject, it is necessary to understand secularization as fantasy. It is within the fantasy of secularization that the secular emerges as an object of desire-as something that, if attained, appears as a solution to the problem of 'foreign' religiosity-and figures of inassimilable religiosity assume the role of scapegoats for the failure to resolve these concerns. In this sense, within this fantasy scene, the secular promises to provide 'us' with something that we are lacking. However, this promise has been undermined by the apparent persistence of religious difference. As such, as a result of their continued religiosity, 'they' appear to be taking something from 'us'.
\end{abstract}

Keywords: secularization; fantasy; integration; social cohesion; diversity; neoliberalism; psychoanalysis; migration

\section{Introduction}

Towards the end of the twentieth century, religion re-emerged as a topic of pressing concern in a number of the most self-consciously secularized states of the global north. From disputes over the wearing of headscarves in schools to debates over what, if any, accommodations should be made for religious practices in the public sphere, religion, particularly the 'foreign' religiosity of migrants and other minority religious subjects, appeared on the scene as a phenomenon requiring immediate attention, about which vital decisions had to be made and arrangements determined, and whose proper place and role in society required both urgent and careful deliberation. Not only did the issue of the regulation of religious diversity escape the narrow realm of specialist bureaucrats and academics to become the focus of widespread and heated public discussions concerning the nature of citizenship, secularism and national identity, it increasingly became the subject of legislative measures and judicial oversight.

In contrast to historical struggles to secularize the public sphere, this wave of apprehension of religion and the religious was not primarily related to imminent concerns over religious control of public institutions nor to the need to limit the excessive homogenizing influence of the Church in social, political and economic affairs. In other words, both the perceived threat posed by religion and the mechanisms deemed necessary to mitigate this threat were transformed. Rather than a concern with secularizing society through cleansing the public sphere of the Church's authority, and thereby protecting citizens from the desire of 'domestic' religious authorities to restrict ways of being and believing, the newly enunciated concern with religion focused primarily on the protection of what were considered already secularized societies from 'foreign' religious threats that, while 
constructed as exogenous, were seen to have already infiltrated the body politic. As such, at the core of contemporary concern with religion is a fear that 'they' are taking something from 'us'.

This threat of 'foreign' religiosity has taken a number of forms. One manifestation is present in the far-right agitation around xenophobic claims of an emergent Eurabia or an impending or already ongoing Islamization of the West. Most prominently, however, the concern with 'foreign' religiosity, and the relentless debates in which it was-and continues to be-implicated, have focused to a greater extent on issues of integration, citizenship, and the nature of secularism. As such, both the concern and the positions taken within these debates have escaped any clear, necessary identification with either the left or the right.

These concerns with religiosity emerged both within the context of the acceleration and consolidation of transformations in the global economy in the final years of the twentieth century that brought to the forefront contradictions within the discourses and practices of secularism, and in relation to processes of othering, misrecognition and stigmatization that structured a particular encounter with difference within this context. However, in order to account for the affective potency produced by the immanence of the figure of the 'foreign' religious subject, this article argues that it is necessary to understand secularization as fantasy.

Understanding secularization in terms of fantasy marks a departure from the manner in which secularization has most often been addressed in the disciplines of sociology and social history. The preponderance of studies have focused on supporting, refuting or refining what has come to be known as the secularization thesis-the assertion that the transition from pre-modernity to modernity had led, or will lead to (a) a marked decline in religious beliefs and practices; (b) a structural differentiation of society into religious and secular spheres; and (c) a marginalization of religion into the private sector (Casanova 1994, pp. 7, 211)—or asserting that, rather than reflecting "an irreversible social process" (Pérez-Agote 2014, p. 888), secularization should be understood as a political project "carried by social actors with specific interests" (Gorski and Altinordu 2008, p. 73). Within these studies, the focus has been on assessing whether the concept of secularization accords with material reality, and if not, either discarding it as a "myth" (Stark 1999), adjusting the concept or developing new concepts to better account for reality.

In this article, I do not approach secularization in terms of fantasy in order to argue that secularization is an inaccurate concept with which to describe the sociological relationship between religion and social change, nor to provide an alternative framework that more accurately describes this relationship. Rather, I do so in order to offer an account of contemporary concerns with 'foreign' religiosity. ${ }^{1}$ In other words, the focus of this article is not the reality of secularization, understood as "authentic or unmediated experience" (Cottrel 2015, p. 89). Instead, consistent with the psychoanalytic approach employed in this article, reality is "a subjective process mediated by desire and constructed discursively" (ibid.). Consequently, the term fantasy is not used to designate a form of perception opposed to reality but as both a scene that stages desire and a relatively stable mode of defense.

In its most general terms, then, the fantasy of secularization is a narrative in which various social forces contribute to a gradual process that directs society and/or individuals towards a secular norm. It is within this fantasy scene of secularization that the secular emerges as an object of desire-as something that, if attained, appears as a solution to contemporary concerns of the integration of religious subjects, long-standing questions of the governance of religion, and more fundamental fears of social antagonism-and figures of inassimilable religiosity assume the role of scapegoats for the failure to resolve these concerns. In this sense, within this fantasy scene, the secular promises to provide 'us' with something that we are lacking. However, this promise is undermined by the apparent persistence of religious difference. As such, as a result of their continued religiosity, 'they' appear to be taking something from ' $u$ s'. 


\section{Fantasy and Desire}

In contrast to the everyday use of the term, within psychoanalytic thought, the relationship between fantasy and reality is not marked by opposition, separation of obfuscation. Fantasy is not a fiction, a screen, a veil, or "a purely illusory production which cannot be sustained when it is confronted with a correct apprehension of reality" (Laplanche and Pontalis [1967] 1973, p. 315). This is not the case because psychoanalytic thought understands fantasy as impervious to the effects of reality. Rather, reality is "not seen as an unproblematic given in which there is a single objectively correct way of perceiving, but as something that is itself discursively constructed" (Evans 1996, p. 60), and, as will be explained below, fantasy is the mechanism through which we construct our reality over the chaos of the Real.

The centrality of fantasy to psychoanalytic thought cannot be understated. Indeed, Freud's 1897 (Freud [1987] 2001) 'discovery' of the importance of fantasy in the etiology of neuroses is often deemed the origin of psychoanalysis proper. In what is commonly referred to as the abandonment of seduction theory, Freud augmented his understanding of neuroses as the symptoms of the repression of memories of infantile sexual abuse, to argue that memories of past events that arise in the course of analysis are not unmediated "traces" of real events but are "continually being reshaped in accordance with unconscious desires" (Evans 1996, p. 60). This movement in Freud's thought may initially seem to support the notion of fantasy as fiction, as an illusion that interferes with a correct perception of material reality, and thus, as is often claimed, a rejection of the veracity of memories of the material reality of sexual abuse as merely psychic reality. While Freud himself seemed at times to retrospectively support this interpretation (Laplanche and Pontalis 1964, p. 315), such an understanding is problematic in two ways. First, Freud's abandonment of seduction theory was not founded on the conviction that memories were false, but on "the discovery of the fundamentally discursive and imaginative nature of memory" (Evans 1996, p. 60). In other words, what Freud was proclaiming as his new discovery was the insight that symptoms did not "originate in any supposed 'objective facts' but in a complex dialectic in which fantasy plays a vital role" (ibid., pp. 60-61).

Second, the interpretation is marked by a misunderstanding of the reality of psychical reality. As Laplanche and Pontalis ([1967] 1973, p. 315) assert, the term psychical reality should not be used to denote all aspects of an 'internal world' or 'psychological domain'. Rather, it refers to "a nucleus within that domain which is heterogenous and resistant and which is alone in being truly 'real' as compared with the majority of psychical phenomena" (ibid.). Thus, while "a particular form of existence not to be confused with material reality," psychical reality is no less real (Freud [1900] 1981, p. 620). Psychoanalytic thought, then, does not approach fantasy as either a distorted image of an actual event or "an imaginary expression designed to conceal the reality of the instinctual dynamic" (Laplanche and Pontalis [1967] 1973, p. 315). Rather, it is the reality of fantasy-its "stability, efficacity and relatively coherent nature" - that psychoanalytic thought seeks to explain (ibid.).

In The Interpretation of Dreams, Freud ([1900] 1981, p. 374) presents fantasy as present at both poles of the process or "journey" of dreamwork. First, fantasies are "bound to unconscious wishes" in what Laplanche and Pontalis ([1967] 1973, p. 316) refer to as the "'capitalist' aspect of the dream," the "starting point of the process of dream formation." Second, fantasy is present in secondary revision-the process which attempts to establish narrative order through the reorganization, censorship or supplementation of fragmentary, incoherent elements, as well as string together "the thread of the wish that runs through" past, present and future in day dreams (Freud [1908] 1981, p. 148). Here we can see the importance of the temporal structure of fantasy. As Freud (ibid., p. 147) explains, "we may say that [fantasy] ... hovers between three times." It is the present that provides "some provoking occasion" that is able to "arouse one of the subject's major wishes." This, then, refers back to a memory of an earlier (usually infantile experience) in which the wish was fulfilled, and constructs "a scene in the future which represents the fulfilment of the wish." What is created is a fantasy, "which carries about it traces of its origin from the occasion 
which provoked it and from the memory" (ibid., pp. 147-48). It is in this threading of a string of desire between past, present and future that the two poles of the journey and the corresponding "modes of phantasy seem therefore to join up, or at least to be linked internally with each other" (Laplanche and Pontalis [1967] 1973, p. 316). While they may be conscious or unconscious, "even where they can be summed up in a single sentence," fantasies are "scripts" of organized scenes which stage desire in the imagination of the subject (ibid., p. 318; Evans 1996, p. 61; Cottrel 2015, p. 89).

While the case of dreams provides a clear illustration of the temporality of fantasy, and the relationship of conscious and unconscious fantasies, fantasies not only "lie behind such products of the unconscious as dreams, symptoms, acting out, repetitive behaviour, etc." but also aspects of behaviour which appear at first glance to be governed solely by the demands of reality" (Laplanche and Pontalis [1967] 1973, p. 317). In fact, as LaPlanche and Pontalis (ibid.) assert, "it is the subject's life as whole which is seen to be shaped and ordered" by fantasy structures.

Jacques Lacan's interventions in psychoanalytic theory are crucial to understanding this structuring role of fantasy. For Lacan ([1975] 1998, p. 14), the goal of psychoanalysis should not be to better orient the analysand towards reality, through "a sort of homeopathic discharge by the subject of his fantasized understanding of the world." Disputing the opposition of reality and fantasy underlying this approach, he asserts that "desire is the essence of reality" (1966, p. 7). As Slavoj Zizek ([1997] 2008, p. 7) explains, what Lacan means is not that fantasy is a form of mental functioning in which we "realize a desire in a hallucinatory way," such as fantasizing about eating a strawberry cake when one desires the cake but is unable to eat it in reality. Rather, fantasy "constitutes our desire," it tells me that I desire a strawberry cake (ibid.).

While in this way, Lacan follows Freud in insisting on an understanding of fantasy as the scene that stages desire, he further emphasizes the protective function of fantasy (Evans 1996, p. 61). In his seminar of 16 November 1966, Lacan states, "reality ... is nothing other than a montage of the symbolic and the imaginary, that the desire, at the centre of this apparatus ... that we call reality, is ... what covers [that which] must be distinguished from human reality, and which properly speaking is the real, which is never more than glimpsed" (Lacan 1966, p. 7). Thus, for Lacan ([1975] 1998, p. 66), the distinction that should be made is between human reality, which is always already symbolic and imaginary, and the real that "resists symbolization absolutely." Likening the fantasy scene to a frozen image on a cinema screen - the result of the film being stopped at a certain point in order to avoid showing a traumatic scene-Lacan (1994, p. 119) states that the fantasy scene fulfils a similar defensive function. The fantasy scene is one that stops just before and serves to veil the traumatic real. As such, the fantasy scene is "the limit where the recollection of history is interrupted; it is a sign of the point of repression" (Nusselder 2009, p. 111). Thus, fantasy is "the primordial form of narrative, which serves to occult some original deadlock" (Zizek [1997] 2008, p. 11). Like all narratives, fantasy seeks to resolve a fundamental antagonism by integrating all elements into a temporal succession. In this way, it is at the same time "the very form of narrative which bears witness to some repressed antagonism" (ibid.).

To state that secularization should be understood in terms of fantasy, then, is not to argue that it is a theory or perception at odds with reality, and should, therefore, be either abandoned or refined in order to better adhere to reality. Rather, it is to assert that secularization is (a) a scene in which desire is staged, and (b) a narrative that serves a protective function.

\section{Secularization as Fantasy}

The introduction to Jakobsen and Pellegrini (2000) special issue of the journal Social Text begins with the intriguing heading, "Dreaming Secularism." While this article, and the remainder of the issue, go on to provide insightful analysis of the discourses and practices of secularism, as well as a variety of attempts to critically engage with the concepts of secularism, secularization and the secular, the notion of dreaming secularism with which it 
began does not reappear. In the article, the concept of 'dreaming secularism' remains only a heading, a curiously unaddressed notion. Yet, the text itself can be seen an example of what it might mean to dream secularism, and therefore, the fantasy of secularization.

Among the paradoxes, inconsistencies and contradictions in secularism and theories of secularization that Jakobsen and Pellegrini $(2000$, p. 6) point to is what they describe as "the problem of difference and modernity." The first aspect of this problem relates to the manner in which secularism has been tied to a positing of simultaneous difference and similarity. What the authors (ibid., p. 9) refer to as Enlightenment equality is said to be universal, in that it applies to all human beings. Yet, in holding Enlightenment values as morally superior in comparison to the exclusionary values of a particular religion, "this very claim to the universal allows for a simultaneous positing of inequality" (ibid.). Secularism purports to allow for the particularization of any religion's universal claims. All religious claims, despite their claims to universalism, are rendered equal as merely perspectives. It is only secular, Enlightenment values and perspectives that retain any claim to universality. As such, Jakobsen and Pellegrini (ibid.) assert, secularization, while providing "the means (and only means) for creating social relations that allow for ... nonviolent relations to substantive difference ... has also been one of the means of evacuating the possibilities of substantive difference." The resulting "paradox" is one in which the form of universal equality that is meant to solve the problem of religious difference introduces a new set of inequalities between the secular and the religious (ibid.).

The second aspect of the 'problem of difference and modernity' that Jakobsen and Pellegrini identify is related to the notion of progress. To narratively resolve the first paradox, time and space are conflated. Cultural differences that are coincident in time but present in different spaces are portrayed as differences in time, "so that all those living in the unenlightened world become the history of those who live in the enlightened world" (Jakobsen and Pellegrini 2000, pp. 9-10). Those groups that seem resistant to the force of secularization are treated as 'failures to secularize,' as anomalies to be accounted for rather than refutations of the secularization thesis (Bruce 2002; Martin 1978).

Until the 1970s, this teleological narrative of secularization as the progressive marginalization, privatization and decline of religion owing to the modernization of society maintained the status of the "reigning dogma" in philosophical and sociological accounts of social change (Swatos and Christiano 1999, p. 209). However, by the late 1960s, there emerged a number of "pressures on the feasibility of this narrative" (Jakobsen and Pellegrini 2000, p. 10). Primary among these pressures was an apparent resurgence of religion-in the form of a rise of conservative religious traditions, 'new' religions or religious movements (such as New Age religions and the popularization of 'Eastern' religions in post-WWII Europe and North America) - that appeared to refute a narrative of religious decline (Hadden 1987, p. 601; Stark 1999, pp. 258-59; Swatos and Christiano 1999, p. 216). Moreover, the upsurge or revitalization of traditional religions did not always take the form of a privatized "invisible religion" (Luckmann 1963), but has often resulted in the emergence of traditional religion as a significant political force (Baum 2001; Casanova 1994; Turner 2003, pp. 358-61).

Critics also argued that, in line with the paradox of universal equality, the narrative of secularization is at once analytic and normative (Casanova 1994, pp. 30-32; Hadden 1987, pp. 587-89; Jakobsen and Pellegrini 2000, p. 4). The opposition of religion and truth, religion and rationality, religion and knowledge, religion and progress, and religion and autonomy, present in the assertions of eighteenth-century figures, such as Thomas Woolston, Frederick the Great and Voltaire, as well as some of the 'founding fathers of sociology', was said to still be present in the work of contemporary secularization theorists such as Robert Bellah (1964) and Parsons (1963). Terms such as rationalization, social differentiation, and complexity are said to represent both functional adaptation and autonomy, and thus function as both descriptive and moral terms, representing structural differentiation and freedom from religious dogma (Hadden 1987, pp. 587-89; Jakobsen and Pellegrini 2000, pp. 4-5). 
In portraying this problem of difference and modernity, and critiquing the notions of universal equality and progress present in the narrative of secularization, Jakobsen and Pellegrini and many other critics do not wish to undermine secularism or somehow combat the process of secularization. Rather, "by questioning what is meant by secular, as well as religion ... [they] hope to disturb the academic order of things, a disturbance that might lead to new support for secularism and, perhaps, to new secularisms, but could also lead to a new relation to religion" (Jakobsen and Pellegrini 2000, p. 2). What they present then is a fantasy scene in which their activity, their questioning or reformulation, can salvage images of secularism and secularization, and bring about a form of society that overcomes this paradox. The problem of religious difference, and even "all substantive difference," can be overcome through secularization, in the form of a secularism which the authors can help realize in a manner that also overcomes the paradox of secularism's universal equality. In this way, fantasy not only provides a scene in which the problem of difference can be resolved, but also an image of the cause of the problem-a particular form of social arrangements. It is in this way that the fantasy of secularization obscures, and thus allows us to avoid confronting what Zizek ([1997] 2008) refers to as the horror of the Real.

However, as Zizek ([1997] 2008, p. 6 fn. 5) describes, in fantasy, "the Horrible can also function as the screen itself, as the thing whose fascinating effect conceals something 'more horrible than horror itself', the primordial void or antagonism." To illustrate this, he provides two examples. The first is the image of a ghost ship drifting along without a living captain or crew to steer it. Here the "ultimate horror" is not that of the "ghost in the machine" - a ghost captain or ghost crew steering the ship—but of "the machine in the ghost: there is no plotting agent behind it, the machine just runs by itself, as a blind contingent device" (ibid.). Similar to this is the fantasy of a Jewish or Masonic conspiracy, which conceals "the horror of society as a contingent mechanism blindly following its path, caught in the vicious cycle of its antagonism" (ibid.). Consequently, even for those who consider the arrival of a secular society as a nightmare, secularization serves as a fantasy scenario in which desire-in this case the desire to arrest the process of secularization-is staged. Envisioning the changes in the place of religion in society as part of the social and/or political process provides the subject with the hope that by understanding the process one can make strategic interventions that will halt or reverse it.

The subject (whether individual or collective) is always present in fantasy, "not only as an observer but also as a participant" (Laplanche and Pontalis [1967] 1973, p. 318). As such, fantasy is a form of dramatization. It is not only an object that the subject fantasizes about attaining, "but rather a sequence in which the subject has his own part to play" (ibid.). The fantasy of secularization is a scenario in which the subject can intervene to help realize or halt the arrival of the secular. Thus, we can understand the investment in debates about the 'reality' of secularization, and the attempts to revise the secularization thesis-albeit often in a reformulated and limited forms (Bruce 2002; Dobbelaere 1981, 2002; Swatos and Christiano 1999; Voyé 1999; Yamane 1997) that exhibit "promiscuous flexibility" (Cox 2003, p. 205) — not merely as scientific endeavours but as inevitably incorporated within a structure of fantasy and desire.

\section{Capital, Cohesion, and the Threat of 'Foreign' Religiosity}

While, what came to be known as France's affaire du foulard — a series of controversies concerning the prohibition of the Islamic headscarf in French schools starting in Creil in 1989 and culminating in the institution of Law 2004-228, which banned the "ostentatious symbols of religion" in public primary and secondary schools-has attained the most widespread international attention, similar intense, heated debates concerning measures restricting the public presence of religious symbols and practices were instituted in a number of the seemingly most already secularized states in the global north since the late 1980s. While this concern with religion, and particularly Islam, is indeed entwined with discourses of orientalism, islamophobia and eurocentrism, it should not be seen as simply a moral panic provoked by certain conservative, racist, and xenophobic political elements. While 
such voices have often garnered the most attention, the problem of religion, in the recent form in which it has emerged, has been raised in many spheres, and has been articulated by individuals and groups representing myriad ideological positions. While disagreeing with the many overtly racist premises of what often takes the form of an anti-Islamic discourse, liberal, socialist, and feminist voices have at times been at the forefront of the articulation of a vital need to contend with issues of fundamentalism, the social integration of immigrants, and the need to delineate the parameters of reasonable accommodation for religious minorities. In France, for instance, teachers associated with Lutte Ouvrière and the Revolutionary Communist League, as well as Ministers in the Socialist government, such as Laurent Fabius and Jack Lang, were among the most prominent voices calling for a prohibition of the hijab in the classroom.

While the specific combination of factors contributing to the rise of recent concerns with 'foreign' religiosity vary, what is common to the various sites in which this concern emerged is the context of a particular attempt by the state to respond to the acceleration and consolidation of the neoliberal economic order. Mitchell Dean (2014) description of neoliberalism as a thought collective and a regime of government, provides a helpful way to approach a phenomenon that has been called "a rascal concept-promiscuously pervasive, yet inconsistently defined, empirically imprecise and frequently contested" (Brenner et al. 2010, p. 182). As a thought collective, neoliberalism is less stable and less coherent than a doctrine, political program or rationality, and more of a "conversation" providing space for "a multiplicity of viewpoints and national and transnational developments, borrowings and mutations" (Dean 2014, p. 151). As such, it can be understood, in part, as "an organized group of individuals with [the] common intellectual framework of ... the desire to renovate free-market liberalism," and oppose manifestations of Keynesian macroeconomic management and the welfare state, including economic protection, government economic planning, intervention and regulation, and large-scale social programs (ibid., pp. 151-52). As a thought collective, neoliberalism has aimed, and was successfully able to transform the powers of government of various institutions, from states to school boards, political parties, universities and international organizations (ibid., p. 156). In doing so, by the late 1970s it had provoked the emergence of a neoliberal regime of government through its influence on individual states and institutions, and, in shaping new international regulatory systems, promoted global conformity.

One way of understanding the emergence with a concern with 'foreign' religiosity is in relation to the destabilizing effect of neoliberal policies. For some, such as Cory Blad (2011), the restrictions that neoliberal globalization has placed on state spending and the state's capacity for economic regulation has required the state to abandon its traditional means of legitimization. Instead, the management and control of national cultural definitions has become an increasingly important strategy for state legitimation. Unable to act as the institution ensuring economic well-being, the state aims to be portrayed as the protector of national culture and identity from the homogenizing forces of globalization. Thus, state measures to restrict displays of 'foreign' religiosity in the public sphere can be seen as attempts by the state to be seen as protecting national culture from the contaminating influence of globalization.

In a similar fashion, others have described the manner in which, in some of the states in which religion has recently emerged as a problem, neoliberal economic reforms posed fundamental problems to national identity (Morrison 2019; Stasiulis 2013). In states, such as Québec, in which the interventionist state was seen as key to "defining and regulating the destiny" of the nation (Juteau 2002, p. 443), economic and social policies were key to a national self-definition grounded in notions of modernization, secularization and progressivism. In the face of neoliberalism, these economic and social provisions became more difficult to maintain, and, as such, a key element of national identity was destabilized. At the same time, an entrepreneurial or hypercapitalist identity was unable to replace state intervention as a sufficient marker of modernization or progressiveness. A vision of progressiveness remained a key element of identity, but one that seemed increasingly 
precarious, at least in the form of social and economic welfare. With the decline of the capacity or willingness of the state to support progressive socio-economic measures, other markers of progressiveness, particularly secularism, and the equality of women, children and sexual minorities increasingly came to the fore. It is in this context that "a growing immigrant population from perceived nonliberal cultures," and particularly their religiosity, became a key "object of worry" (Stasiulis 2013, p. 6).

The reaction of states to the pressures of neoliberal globalization has not, however, been limited to austerity. While some have depicted a differentiation between what they label the "roll back" and "roll out" phases or dimensions of neoliberalism (Peck 2010, pp. 21-25), others have described, to borrow Dean's terms, the introduction of an alternative regime of governance brought about by the ascendancy of a new thought collective reacting to what they perceive as the threats and opportunities of the new global economy through the advancement of policies that were "neither purely neoliberal nor Keynesian" (Dobrowolsky and Saint-Martin 2005, p. 6). By the late 1980s, the shift towards economic and social policies inspired by neoliberalism had resulted in income polarization, persistent poverty and other serious social strains (Jenson and Saint-Martin 2003, p. 77). In reaction to this, by the early 1990s, consensus had formed in policy communities in Europe, the United Kingdom and Canada about the need to counteract the threat of social and national dissolution arising from the atomization, social exclusion, and potential creation of a permanent underclass arising from the deepening of neoliberal socio-economic relations and an associated intensified immigration.

While politicians and policy experts repeatedly articulated a belief that a re-introduction of the welfare state would render states uncompetitive in the global economy, they feared that neoliberal policies and austerity measures had led, and would increasingly lead to an intensification of social exclusion. To contend with this threat of social exclusion, policies and programs were developed with the aim of protecting individuals and society from the negative effects of global economic transformations through the inclusion and activation of marginalized groups and individuals. While the specific methods to achieve inclusion and social cohesion differed between states, there existed a shared belief that attending to these issues was an urgent task that could only be accomplished by state intervention.

Whether framed as the Third Way, modernizing the European social model, a new social democracy, the social economy or the social investment state, the response to the consolidation of a neoliberal global economy did not only involve cuts but also the introduction of a new vision and new practices of social investment (Daniel and Palier 2001). As such, the new regime of governance rejected both the social expenditure approach of the welfare state, and the over-reliance on market forces, the voluntary sector, the family, and individual responsibility for generating "life-chances" associated with neoliberalism. Unlike the post-war welfare regime of social citizenship, which sought to protect people from the market, focus was placed on the "activation of the labour force" through policies designed to "act as a trampoline for the integration of people into the market through education, training and other programmes that sustain labour force participation" (Jenson and Saint-Martin 2003, p. 83). In this sense, the "goal of equality [was] displaced by the goal of social inclusion" (Dobrowolsky and Saint-Martin 2005, p. 8).

The focus on inclusion within the new regime of governance was not, however, limited to questions of labor force participation. Rather, it sought to combat social exclusion through the implementation of policies targeting the inclusion of all citizens through a focus on training, early childhood education and development, and the integration of migrants and minority communities. In relation to the later, states introduced measures to promote access and equity for minority groups, as well as the much more controversial practice of requiring public institutions to make 'reasonable accommodations' for the cultural practices of minority groups, mostly with concern to religious practices. The inclusion and integration of all citizens was seen as both the result of, and a prerequisite to a stable, secure, and prosperous society. Thus, these measures were seen as key to preventing the 
development of an underclass of unemployed or underemployed individuals, the creation of maintenance of ethnic ghettos, and social and national fragmentation.

It was within this context of a profound concern with social exclusion that 'foreign' religiosity emerged as a concern within a number of the states that would come to be exemplary of this new regime of governance. This religiosity appeared as a particular obstacle to integration, and, as such, a threat to society. As Coryse Ciceri (1998) notes in her thorough analysis of the headscarf debates in France and Québec in the early to mid 1990s, social cohesion was a major concern, not only for advocates of prohibiting the hijab in public schools but also for opponents of this measure. For proponents of the prohibition, the public donning of the headscarf is associated with a defiant display of difference, representing not only a refusal of immigrants to integrate into broader society and their greater identification with the wider Islamic world than with their fellow citizens that they argue retards the integration Muslims in Québec (Conseil du statut de la femme du Québec 1995, p. 31). This 'refusal' to integrate is linked to a second perceived threat to social cohesion, namely the undermining of common values, culture and identity. As articulated by the journalist François Brousseau (as quoted in Lenk 2000, p. 84), this threat is one of "lebanonization, balkanization, yugoslavization." As such, "modern societies all have a need for diversity, tolerance of multiplicity and difference. But they also have a need for cohesion and shared references" (ibid.).

This concern with social cohesion was also central to the arguments of opponents of a prohibition of the hijab in public schools. In particular, they focused on the threat of Islamic fundamentalism. First, restricting those Muslim girls who don the hijab from attending public schools was said to risk the creation of a marginalized group. The consequences of this exclusion were not simply a denial of economic opportunities but, more importantly, the denial of the opportunity to be integrated into common social and national values. The stakes of integration were portrayed as particularly high owing to the perception of Islamic fundamentalism as a "spreading disease", particularly rampant in suburbs where it appears "one is in Iranian, Egyptian, Maghrebian, Pakistani, etc. territory" (Lenk 2000, p. 83). As it is from such "neighbourhoods with a high density of immigrants that fundamentalists emerge" (Bensalem 1994), excluding young Muslims from public schools, would leave them as easy prey for fundamentalists.

Understood in this way, the public school has the responsibility to transmit common civic and national values (Ciceri 1998, p. 92). The school serves as place in which the religious constraints of parents are relaxed and children are free to forge their own identity. In this space, students not only engage in an internalization of common values, but also learn how to moderate their identity and put certain differences in parentheses when in the public sphere. In other words, they learn how to behave as a secular citizen. The teaching of common values within this secular space contributes to a relativization of the values of the family and religious/cultural community. Moreover, within the framework of the new regime of social investment, the child, as malleable, was seen as a particularly good site of targeted investment (Dobrowolsky and Saint-Martin 2005). Investing in the health and education of children in poor and otherwise marginalized families, was seen as giving them the best change at social integration. In this way, the school serves as a space for the transformation/secularization of the student (McAndrew 2006, p. 3). To block the access of Muslim girls to public education, critics argued, would inhibit their integration into society.

Shared by both proponents and critics of the prohibition of the hijab in public schools, then, is a view of the 'foreign' religious subject as a threat to social cohesion. Consequently, they must be acted on. If they are included in the public sphere, they are said to undermine common values, and thus social cohesion. As such, they should be removed. However, if removed from the public sphere they are subject to the particularist, and even dangerous, ideologies of their religious community, and, thus, are a threat to social cohesion. It is both (a) the seeming irresolvable nature of the question of the presence of 'foreign' religiosity in ostensibly secularized space, and (b) the fantasy scene of a form of secularism that can resolve the dilemma of religious difference, eliminating what appears as perhaps the 
primary obstacle to social cohesion, and thus realizing the attainment of national unity, stability and prosperity, that, since the late 1980s, has both animated and reproduced an intense concern with issues of secularism and integration. In this sense, as Adam Cottrel (2015, p. 90) asserts, "while fantasy might not provide us with the object itself, it can provide us something of equal consequence: the scene of attaining the privileged object that renders attainment as a possibility."

\section{Religious Difference and the Theft of Enjoyment}

Neither an anxiety in the face of the threat to governance, unity and prosperity posed by the presence of religion in the public sphere, nor a fantasy structure in which this threat can be resolved are, of course, unique to the contemporary moment. Throughout history there have been ongoing attempts to manage the threat of the presence of-what we would now refer to as religion-within the political community (Morrison 2014). This threat has often been associated with two related issues-whether the primary loyalty of religious subjects lies with the broader community or their religious community; and whether religious subjects will, in the case of a conflict of laws or values, follow the dictates of religious or secular authority. At least in part, these suspicions have often been related to an uneven reward and punishment structure, in which neither the rewards for loyalty nor the punishments for disloyalty that can be offered by this-worldly authority can match those of a super-natural authority. Thus, even religious rulers and theocratic forms of governance have often been wary of the possibility of disloyalty in the case of alternative interpretations of the wishes of a higher power or the true nature of a religion. As such, the current crisis of religious pluralism can be seen as the contemporary materialization of both a perennial anxiety concerning religious difference and a failure to resolve the question of the governance of religious subjects.

However, to understand the force of fantasy, the form in which religion continues to appear as a threat, and the continued desire to resolve the dilemma of religious difference, it is necessary to address how, within the fantasy of secularization, the secular takes the form of the privileged object, serving as what Lacan labels the object petit $a$ or the objectcause of desire. As Zizek ([1997] 2008, p. 15) explains, this paradoxical object "emerges as being-lost." Rather than an object that we once possessed but have now lost, in the very moment that the object emerges it does so as already lost. It is this paradox that fantasy-through the narrativization of attainment followed by loss-occludes. The state of wholeness and perfect drive satisfaction is an illusion that we retroactively produce in the moment that restrictions are placed on jouissance. In entering the symbolic order and becoming subject to the Law, the petit object a emerges as a reserve of the jouissance we had to sacrifice in becoming socialized. In the words of Lacan ([1973] 1998, p. 101), "the object $a$ is something which the subject, in order to constitute itself, has separated off as organ ... It must, therefore, be an object that is, firstly, separable and secondly, that has some relation to lack." The restriction required by the entry into the symbolic, the requirement to seek enjoyment in ways that are socially permitted, is what Lacan refers to as symbolic castration. The sense of loss is not simply one of the loss of an external object but of missing a part of oneself. It is this part of oneself, that is the object petit $a$.

As Zizek ([1997] 2008, p. 43) states, "fantasy is the narrative of this primordial loss, since it stages the process of this renunciation, the emergence of the Law." However, fantasy stages this loss in such a way as to veil the scene of castration (Lacan 1994, pp. 119-20). In other words, fantasy serves as a screen upon which a particular object or idea provides a solution to the dissatisfaction of reality (Cottrel 2015, p. 90). Politically, therefore, fantasy can placate unrest through what Cottrel (ibid.) refers to as "depoliticizing the social body," distracting it from directly engaging with the dissatisfaction of lack. In the case of the fantasy of secularization, the attainment of the secular, in the form of a society in which religious difference no longer poses a threat, promises to resolve concerns about social dissolution. It does so, however, in a manner in which society, if not faced with this challenge, would be unified, stable and prosperous. In this way, it stages a scene of loss-a 
form of society that we would have if not faced with the problem of religious difference-in which a lack - in this case, of a unified, stable society-that covers over, yet represents the scene of castration.

Fantasy also provides us with figures who are held responsible for this loss or lack. Within fantasy the promise of satisfaction, the access to the reserve of lost enjoyment, is tied to the attainment of an externalized lost object. The fantasy scene contains the image of a non-lacking subject, one who experiences an impossible enjoyment. It provides us a scene in which this impossible enjoyment is realized. Consequently, there must be someone who has obtained this enjoyment. Thus, "because we are able to fantasize an impossible enjoyment, we also misattribute this impossibility to an Other that seems to enjoy in a way that we cannot experience but only imagine" Cottrel 2015, p. 91). It is in this sense that we can understand the Lacanian notion of the theft of enjoyment. As Zizek ([1997] 2008, p. 43) argues, "fantasy provides a rationale for the inherent deadlock of desire: it constructs the scene in which the jouissance we are deprived of is concentrated in the Other who stole it from us."

The other, then, appears to have what we lost. This does not mean that within the fantasy of secularization some other group is seen as having obtained the secular that we desire, and that we fantasize about retrieving it from them. Rather, their other's religiosity, and the enjoyment we imagine they attain from it, is seen as restricting our enjoyment. What is disturbing about 'foreign' and minority religious subjects is not that their beliefs and practices appear as strange or backward, that they are incomprehensible to us or symbolically at odds with our own practices, but that the excessive way in which they pursue their enjoyment restricts our own. Their form of religiosity, from which they derive enjoyment, appears as an obstacle to social cohesion, and thus to a unified, stable and prosperous society. More specifically, in contrast to Christianity, which, within traditional narratives of secularization has been tamed-either by its transformation into a historical relic representing a cultural heritage (Morrison 2019, p. 4) or the positing of "a sociohistorical paradigm in which Christianity and the secular form a necessary and symbiotic relationship" in visions of European exceptionalism (Morrison 2013, p. 149)—-the 'foreign' and minority religious subject appears as a threat to social cohesion and to the fabric of the secular democratic nation state.

Attributing the theft of enjoyment to an other, therefore, serves to conceal "the traumatic fact that we never possessed what was allegedly stolen from us" (Zizek 1993, p. 203). Thus, the hatred of the other's enjoyment is really a hatred of the limitations of our forms of enjoyment (ibid., p. 206). The 'foreign' or minority religious subject did not steal our unity and stability because society is always an unstable site of antagonism. In social or political terms, when we complain about the excessive enjoyment of the other, what we are pointing to is not the incompatibility of their cultural practices with our own, but to the inherent antagonisms within our own community. Within fantasy, then, the other, as she who steals our enjoyment, plays the role of the scapegoat.

Yet it is this displacement of inner-group social antagonism that sustains our desire (ibid., p. 206). While what Zizek (2017, p. 210) labels the "beatific" dimension of fantasy, the promise of fulfilment through attainment of the privileged object is sustained by the partial and fleeting moments of enjoyment that the object provides, the "disturbing paranoic fantasy ... tells us why things went wrong." Blaming 'foreign' religiosity allows us to continue to invest in the project of secularism while providing us with a reason why it has not yet delivered on its promise. Thus, the figure of the scapegoat "preserves our faith in the existence and possibility of recapturing our lost enjoyment ... but projects its full realization onto the future, when we will get it back from the Other who has stolen it from us" (Stavrakakis and Chrysoloras 2006, p. 152). In this way, by maintaining enjoyment at "a healthy distance," (ibid.), as something that can be attained in the future, fantasy maintains the secular as an object of unfulfilled desire. 


\section{Conclusions: Traversing the Fantasy of Secularization}

The purpose of the psychoanalytic approach undertaken throughout this article is not, as previously mentioned, to lead the reader to an understanding of the world more in line with reality, and thereby discharge their fantastical understanding of the world. Rather, it is the traversal of the fantasy of secularization. In clinical terms, traversing a fantasy involves addressing the unconscious fundamental phantasy that lies beyond the various conscious fantasies. In a neurotic fantasy, such as the fantasy of secularization described above, the other is held culpable for our lack. The fantasy thus ferments an obsession "with the notion that the sacrificed jouissance, the jouissance 'taken' from her, is stored somewhere in the Other who is profiting from it 'illegitimately" (Zizek [1997] 2008, p. 44). Traversing the fantasy does not mean somehow abandoning fantasy, but rather, "renouncing the myth that jouissance has to be amassed somewhere else" (ibid., p. 43). In other words, psychoanalysis seeks to intervene to help us stop blaming an other, whether in the form of society, our parents, the church, our spouse, the 'foreign' or minority religious subject, etc., for our lack, and, "consequently, to stop seeking retribution from the Other" (ibid., p. 45).

Thus, to state that secularization is a fantasy is not to imply that it is an error or illusion at odds with reality. It calls neither for the renunciation of the status of secularization as a scientific concept, or for a conceptual refinement so the term better accords with reality. Rather, the fantasy of secularization is understood as a scene in which the secular as the object of desire-as the privileged object that, provides a solution to issues of religious difference and social cohesion, and thereby permits the realization of a society free of social antagonism-and 'foreign' and minority religious subjects as the scapegoats for our failure to resolve these concerns emerge. Traversing the fantasy does not involve undermining the desire to resolve questions of religious difference and social antagonisms. Rather, it allows us to do so without blaming 'foreign' religiosity for the persistence of social antagonisms. In doing so, it frees us to seek enjoyment not somewhere else but in the very activity of working towards the attainment of these goals through a transformation of the basic structures of society.

Funding: This research was funded by the Andrew W. Mellon Foundation, grant number 1807-06037. The APC was funded by The American University in Cairo.

Conflicts of Interest: The author declares no conflict of interest. The funders had no role in the design of the study; in the collection, analyses, or interpretation of data; in the writing of the manuscript, or in the decision to publish the results.

\section{Notes}

1 The analysis here is limited to that of states in the global north in which concern with religion has taken this form in recent decades. Both the form of concern with religious difference and that fantasy of its resolution take different forms elsewhere, particularly in societies outside of the global north, due, at least in part, to legacies of colonialism.

\section{References}

Baum, Gregory. 2001. Nationalism, Religion, and Ethics. Montreal: McGill-Queen's University Press.

Bellah, Robert. N. 1964. Religious Evolution. American Sociological Review 29: 358-74. [CrossRef]

Bensalem, Leila. 1994. Le voile islamique ou le refus de s'intégrer à la société québécoise. La Presse, October 13, B-3.

Blad, Cory. 2011. The Paradoxical Return of National Culture in the Globalization Era: Theorizing Present and Future State Legitimation. Race, Gender \& Class 18: 329-47.

Brenner, Neil, Jamie Peck, and Nik Theodore. 2010. Variegated Neoliberalization: Geographies, Modalities, Pathways. Global Networks 10: 182-222. [CrossRef]

Bruce, Steve. 2002. God Is Dead: Secularization in the West. Oxford: Blackwell.

Casanova, José. 1994. Public Religions in the Modern World. Chicago: University of Chicago Press.

Ciceri, Coryse. 1998. Le Foulard Islamique à L'école Publique: Analyse Comparée du Débat dans la Presse Française et Québécoise Francophone (1994-1995). Ph.D. thesis, Faculté de l'éducation, Université de Montréal, Montréal, QC, Canada.

Conseil du statut de la femme du Québec. 1995. Réflexion sur la Question du Port du Voile à L'école. Québec: Gouvernement du Québec. Cottrel, Adam. 2015. Fantasy. In The Žižek Dictionary. Edited by Rex Butler. New York: Routledge, pp. 89-92.

Cox, Jeffrey. 2003. Master Narratives of Long-Term Religious Change. In The Decline of Christendom in Western Europe, 1750-2000. Edited by Hugh Mcleod and Werner Ustorf. Cambridge: Cambridge University Press, pp. 201-17. 
Daniel, Christine, and Bruno Palier. 2001. La Protection Sociale en Europe. Le Temps des Réformes. Paris: La Documentation Française.

Dean, Mitchel. 2014. Rethinking Neoliberalism. Journal of Sociology 50: 150-63. [CrossRef]

Dobbelaere, Karel. 1981. Secularization: A Multi-Dimensional Concept. Current Sociology 29: 3-153. [CrossRef]

Dobbelaere, Karel. 2002. Secularization: An Analysis at Three Levels. Brussels: PIE-Peter Lang.

Dobrowolsky, Alexandra, and Denis Saint-Martin. 2005. Agency, Actors and Change in a Child-Focused Future: 'Path Dependency' Problematised. Commonwealth \& Comparative Politics 43: 1-33. [CrossRef]

Evans, Dylan. 1996. An Introductory Dictionary of Lacanian Psychoanalysis. London: Routledge.

Freud, Sigmund. 1981. The Interpretation of Dreams. In The Standard Edition of the Complete Psychological Works of Sigmund Freud, Volume V: The Interpretation of Dreams (Second Part) and on Dreams. Translated and Edited by James Strachey. London: Hogarth Press, pp. 339-627. First published 1900.

Freud, Sigmund. 1981. Creative Writers and Day-Dreaming. In The Standard Edition of the Complete Psychological Works of Sigmund Freud, Volume IX: Jensen's 'Gradiva' and Other Works (1906-1908). Translated and Edited by James Strachey. London: Hogarth Press, pp. 141-53. First published 1908.

Freud, Sigmund. 2001. Letter 69. Extracts from the Fliess Papers. In The Standard Edition of the Complete Psychological Works of Sigmund Freud, Volume I (1886-1899): Pre-Psycho-Analytic Publications and Unpublished Drafts. Translated and Edited by James Strachey. London: Penguin, pp. 259-60. First published 1987.

Gorski, Philip S., and Ates Altinordu. 2008. After Secularization. Annual Review of Sociology 34: 55-85. [CrossRef]

Hadden, Jeffrey K. 1987. Towards Desacralizing Secularization Theory. Social Forces 65: 587-611. [CrossRef]

Jakobsen, Janet R., and Ann Pellegrini. 2000. World Secularism at the Millennium: Introduction. Social Text 18: 1-27. [CrossRef]

Jenson, Jane, and Denis Saint-Martin. 2003. New Routes to Social Cohesion? Citizenship and the Social Investment State. The Canadian Journal of Sociology 28: 77-99. [CrossRef]

Juteau, Danielle. 2002. The Citizen Makes an Entrée: Redefining the National Community in Quebec. Citizenship Studies 6: 441-58. [CrossRef]

Lacan, Jacques. 1998. The Seminar of Jacques Lacan, Book XI. The Four Fundamental Concepts of Psychoanalysis. Edited by Jacques-Alain Miller. Translated by Alan Sheridan. New York: WW Norton. First published 1973.

Lacan, Jacques. 1998. The Seminar of Jacques Lacan, Book I. Freud's Papers on Technique. Edited by Jacques-Alain Miller. Translated by John Forrester. New York: Norton. First published 1975.

Lacan, Jacques. 1966. Seminar 1: Wednesday 16 November 1966. In The Seminar of Jacques Lacan, Book XIV: The Logic of Fantasy $1966-1967$. Translated by Cormac Gallagher. pp. 2-12, unpublished. Available online: http:/ / www.lacaninireland.com/web/wp-content/ uploads /2010/06/14-Logic-of-Phantasy-Complete.pdf (accessed on 2 June 2021).

Lacan, Jacques. 1994. Le Séminaire. Livre IV. La relation d'object, 1956-57. Edited by Jacques-Alain Miller. Paris: Seuil.

Laplanche, Jean, and Jean-Bertrand Pontalis. 1973. The Language of Psychoanalysis. London: Karnac. First published 1967.

Laplanche, Jean, and Jean-Bertrand Pontalis. 1964. Fantasme originaire, fantasmes des origines, origine du fantasme. Les Temps Modernes 19: 1833-68.

Lenk, Helle-Mai. 2000. The Case of Émilie Ouimet: News Discourse on Hijab and the Construction of Québécois National Identity. In Anti-Racist Feminism. Edited by Agnes M. Calliste and George J. Sefa Dei. Halifax: Fernwood, pp. 73-90.

Luckmann, Thomas. 1963. The Invisible Religion: The Problems of Religion in Modern Society. New York: Macmillan.

Martin, David. 1978. A General Theory of Secularisation. Oxford: Blackwell.

McAndrew, Marie. 2006. Le cas de l'école. In L'affirmation religieuse menace-t-elle l'égalité des sexes? Diversité de foi, égalité de droits. Québec: Conseil du Statut de la Femme. Available online: https:/ / cybersolidaires.typepad.com/ameriques/2006/12/diversit_de_foi.html (accessed on 2 May 2021).

Morrison, Ian. 2013. Christianity, Secularism and the Crisis of Europe. In Europe after Derrida: Crisis and Potentiality. Edited by Agnes Czajka and Bora Isyar. Edinburgh: Edinburgh University Press, pp. 149-62.

Morrison, Ian. 2014. The Crisis and Governance of Religious Pluralism in the European Union. Insight Turkey 16: 55-67.

Morrison, Ian. 2019. Moments of Crisis: Religion and National Identity in Québec. Vancouver: UBC Press.

Nusselder, André. 2009. Interface Fantasy: A Lacanian Cyborg Ontology. Cambridge: MIT Press.

Parsons, Talcott. 1963. Christianity and Modern Industrial Society. In Sociological Theory, Values, and Sociocultural Change: Essays in Honor of Pitrim A. Sorokin. Edited by Edward A. Tiryakian. New York: Free Press, pp. 33-70.

Peck, Jamie. 2010. Constructions of Neoliberal Reason. Oxford: Oxford University Press.

Pérez-Agote, Alfonso. 2014. The Notion of Secularization: Drawing the Boundaries of its Contemporary Scientific Validity. Current Sociology 62: 886-904. [CrossRef]

Stark, Rodney. 1999. Secularization, R.I.P. (Rest in Peace). Sociology of Religion 60: 249-64. [CrossRef]

Stasiulis, Daiva. 2013. Worrier Nation: Quebec's Value Codes for Immigrants. Politikon 40: 183-209. [CrossRef]

Stavrakakis, Yannis, and Nikos Chrysoloras. 2006. (I Can't Get No) Enjoyment: Lacanian Theory and the Analysis of Nationalism. Psychoanalysis, Culture \& Society 11: 114-63. [CrossRef]

Swatos, William H., and Kevin J. Christiano. 1999. Secularization Theory: The Course of a Concept. Sociology of Religion 60: $209-31$. [CrossRef]

Turner, Bryan S. 2003. Historical Sociology of Religion: Politics and Modernity. In Handbook of Historical Sociology. Edited by Gerard Delanty and Engin F. Isin. London: SAGE, pp. 349-63. 
Voyé, Lilian. 1999. Secularization in a Context of Advanced Modernity. Sociology of Religion 60: 275-83. [CrossRef] Yamane, David. 1997. Secularization on Trial. In Defense of a Neosecularization Paradigm. Journal for the Scientific Study of Religion 36: 109-22. [CrossRef]

Zizek, Slavoj. 2008. The Plague of Fantasies. London: Verso. First published 1997.

Zizek, Slavoj. 1993. Tarrying with the Negative: Kant, Hegel, and the Critique of Ideology. Durham: Duke University Press.

Zizek, Slavoj. 2017. The Seven Veils of Fantasy. In Key Concepts of Lacanian Psychoanalysis. Edited by Dany Nobus. London: Karnac, pp. 190-218. 